\title{
From frequent hurricanes to the Deepwater Horizon oil spill in coastal Louisiana: the impact of regulatory change
}

\author{
$\underline{\text { So-Min Cheong }}{ }^{1}$
}

ABSTRACT. The issue of whether adaptations to past disasters can impede adaptation to new disasters of a different type or intensity will be analyzed by examining the transition from frequent hurricanes to the Deepwater Horizon oil spill in coastal Louisiana. In particular, the effects of changed regulatory structures from the Stafford Act to the Oil Pollution Act of 1990 in response to the Deepwater Horizon oil spill are investigated. The article describes how the federal, state, and local governments adjust. In addition, it illustrates the shifting focus on the environment with the activation of the Oil Pollution Act and the Clean Water Act. It wraps up with a discussion of the uncertainty that is pervasive in the case of the oil spill derived from changed regulations and the novelty of the disaster.

Key Words: disaster response; government; hurricanes; oil spill; regulation

\section{INTRODUCTION}

Established ways of behavior are commonly shaped by people's previous experience of disasters but this can, paradoxically, hinder their timely adaptation to new or different, high-impact environmental changes. Established expectations in terms of disaster response and compensation can lead to confusion and resentment when further environmental change occurs. Learning that transfers from one event to a similar event (e.g., from one flood to the next flood) leads to the assumption that this learning transfers to other, different disasters. Because of lack of comparative work, people may commonly accept that experience of one environmental disaster (e.g., experiencing 2005 Hurricane Katrina) can increase people's resilience and capacity to adapt to different, new hazards (National Academies 2012).

The objective of this study is to establish whether adaptations to past disasters can impede adaptation to new disasters of a different type or intensity by examining the transition from frequent hurricanes to the Deepwater Horizon oil spill in coastal Louisiana. In particular, the effects of changed regulatory structures from the Stafford Act to the Oil Pollution Act of 1990 in response to the Deepwater Horizon oil spill will be investigated. The initial impacts of these regulatory changes were confusion, resentment, and a heightened sense of uncertainty. The reasons for these responses will be examined. First, the ways federal, state, and local governments have adjusted to the new set of regulations will be investigated. This will be followed by a discussion of a shift of emphasis to the environment after the oil spill compared to the focus on people in the event of hurricanes. Finally, the uncertainty pervasive in the case of the Deepwater Horizon oil spill will be assessed and the cause of heightened uncertainty attributed to changed regulations and the novelty of the disaster rather than the magnitude of the spill.

\section{METHOD}

Content analysis was conducted using archival sources and policy documents, reports on disaster response from major online sources, public records and proceedings, and newspaper articles (see Table 1). An inductive approach was employed to observe particular instances and combined them to extract a general pattern. This approach is used if there is a lack of knowledge about the phenomenon and knowledge is fragmented (Elo and Kyngäs 2008). The documents were carefully reviewed first and then open coding and categorization was carried out. Three main categories are the impact of changed regulations on federal, state, and local governments; environmental recovery; and uncertainty.

Table 1. Major sources and agencies for content analysis and interviews

\begin{tabular}{|c|c|}
\hline & Louisiana \\
\hline $\begin{array}{l}\text { Sources (for } \\
\text { content analysis) }\end{array}$ & $\begin{array}{l}\text { Gulfrestoration.gov, documents from the } \\
\text { governor's oil spill office, governor's coastal } \\
\text { restoration group, St Bernard, Terrebonne, } \\
\text { Plaquemines, and Lafourche parishes } \\
\text { police juries, Minerals Management } \\
\text { Service/BOERME material, post-spill } \\
\text { congressional hearings, New Orleans } \\
\text { Times-Picayune, Houma, Morgan City, } \\
\text { Lafayette newspapers, blogs (e.g., Len } \\
\text { Bahr) }\end{array}$ \\
\hline $\begin{array}{l}\text { Agencies (for key } \\
\text { informant } \\
\text { interviews) }\end{array}$ & $\begin{array}{l}\text { NOAA, Coast Guard, Ocean Conservancy, } \\
\text { GCCF, Gulf Restoration Network, } \\
\text { Catholic Charities, Parish presidents, } \\
\text { Governor's office staff }\end{array}$ \\
\hline
\end{tabular}

Content analysis is complemented by semi-structured interviews with key informants such as national, state, and local government officials, researchers at nongovernmental organizations, and community leaders (see Table 1). Purposive and snowball sampling were used to select 20 key participants in Louisiana. Interview questions concentrated on the differences between hurricanes and the oil spill, people's responses to both, and the impact of changed regulations on oil spill response and recovery.

\section{REGULATORY CHANGE}

Government, as a provider of public goods and enforcer of laws and regulations, is a key player in shaping disaster response. The impact of government policies and regulations on disaster management is fundamental to understanding how governments and communities adapt to disasters. They are a neglected area of research, however, as the focus tends to be limited to hazard mitigation planning (Reddy 2000, Bulkeley and Kern 2006, Burby 2006). Studies of the consequences of government policies at the 
local level are mainly concerned with the distorted effects of the national flood insurance and a lack of consultation with the local community (Burby 2006, Depoorter 2006, Ribot et al. 2006, Geiser and Rist 2009).

In the case of the BP Deepwater Horizon spill, the transition from hurricanes to the spill caused much confusion at the initial phase of response. The Stafford Act worked well for the Gulf states when they were struck by hurricanes. However, response and management of the BP Deepwater Horizon oil spill was framed under the Oil Pollution Act (Foley 2011) and has led to conflicts, misunderstandings, and resentment partly due to the shift in the legal framework applied (National Commission on the BP Deepwater Horizon Oil Spill and Offshore Drilling 2010, Birkland and DeYoung 2011). Hurricanes and oil spills are both viewed by the public as environmental disasters. Consequently, public expectations regarding disaster response and recovery, which had been shaped by the Stafford Act, did not match well with the mandates of the Oil Pollution Act. Residents of the Gulf states were resentful of the seemingly top-down decision-making led by the Coast Guard that replaced governance shared by the state and the federal bodies under the Federal Emergency Management Agency (Birkland and DeYoung 2011).

The application of different regulatory policies and frameworks in the case of the oil spill required some behavioral change by the affected states and communities. The implementation of these policies tailored to the new mega-disaster in coastal Louisiana widened the gap between what people were used to (and expected) and what was now required of them. Though learning and trust are critical to overcoming the gap and sustain resilience (Longstaff and Yang 2008, Gunderson 2010), they have taken place retroactively after much confusion and resentment.

\section{Federal vs. state vs. local}

At the federal level, institutional disjuncture existed between the U.S. Coast Guard and the Department of Homeland Security during the BP Deepwater Horizon spill response. The Coast Guard activates and heads the National Contingency Plan under the Oil Pollution Act (Figure 1). It also leads the unified command structure as the federal on-scene coordinator. Its main task is to provide a forum for consensus decision-making by all the organizations responsible for and responding to the incident. In addition to the unified area command, three incident command posts in Houma, Louisiana; Houston, Texas; and Mobile, Alabama made key tactical and operational decisions during the oil spill crisis (United States Coast Guard 2011a).

On the other hand, the Department of Homeland Security operates on the National Response Framework based on the Stafford Act to deal with disasters (Figure 1). The National Response Framework evoked during disasters such as hurricanes places responsibilities at the local level with support from the state and federal governments only when the disaster exceeds local capabilities. This contrasts with the National Contingency Plan in which there is little direct local involvement. That is, the Coast Guard is required to consult and ask input from the state via the state on-scene coordinator but not necessarily from the local government. Because of these differences, the Coast Guard developed a policy in 2009 addressing "connectivity with the National Response Framework," although the implementation of this policy is yet to materialize (United States Coast Guard $2011 b)$.
Initially the most notable problem was in the area of crisis communication. The decision by the White House and the Department of Homeland Security to create a National Response Framework crisis communications model clashed with the Coast Guard's National Contingency Plan (United States Coast Guard $2011 a, b)$. The United States Coast Guard $(2011 a, b)$ report states that external and public affairs functions became very centralized, and information from the command centers at Houma and Mobile were not conveyed well. The incident commanders were also unsure of the restrictions regarding their interaction with the media. This ran contrary to the National Contingency Plan's objective to decentralize their communications and provide realtime information. Because this oil spill was a "Spill of National Significance," a National Incident Command was also activated to respond to high-level political and media inquiries. Furthermore, the involvement of several federal agencies added additional layers of review and approval that stalled timely crisis communication and information on the status of the response. Untrained or under-trained staff in the Coast Guard's public affairs program was used because the magnitude of the spill required increased number of staff to work in all areas, including communications.

The role of the Coast Guard also changed from search and rescue during hurricanes to the monitoring of cleanup during the oil spill. Though staff other than the oil-response division was involved, the Coast Guard division responsible for oil spills was not the same division as the one activated during hurricanes. During hurricanes, members of the Coast Guard are actually physically present and save lives. They become heroes in the eyes of the people. During hurricanes, the Federal Environmental Management Agency (FEMA) takes the lead in making decisions in cooperation with state and local governments about aids and trailers. During the spill, however, the situation was reversed, and the Unified Command with the Coast Guard at the helm made decisions with respect to oil spill response. Unlike during hurricanes, the Coast Guard did not have much physical presence in terms of individual contacts. For example, it was not noticeably visible capping oil because the former Minerals Management Service and BP had more technological knowledge and expertise to cap the spill (Griggs 2011). The Coast Guard staff felt that the Coast Guard had less opportunity to shine than it did during Katrina. One staff member remarked, "we were seen as good guys during the hurricanes, and bad guys during the spill."

During the oil spill, there were complex issues at the federal level, and the oil spill response was not necessarily the straightforward, top-down command system that people recognized it to be. People perceived the Coast Guard to be top-down because it functions like a military organization, and its response operation contrasts with the bottom-up hurricane responses that people are used to. One member of the Coast Guard staff notes that the response may have been more top-down because the oil spill was treated as a special case of clean up that could not be entrusted entirely to locals. The same staff cites necessity of speed as an important factor for running a top-down operation.

In some instances, the National Contingency Plan worked well with other federal agencies. The Environmental Protection Agency, National Ocean and Atmospheric Administration, and United States Geological Survey made important decisions outside of the command structure (Osofsky 2011). The 
Fig. 1. National Response Framework vs. National Contingency Plan

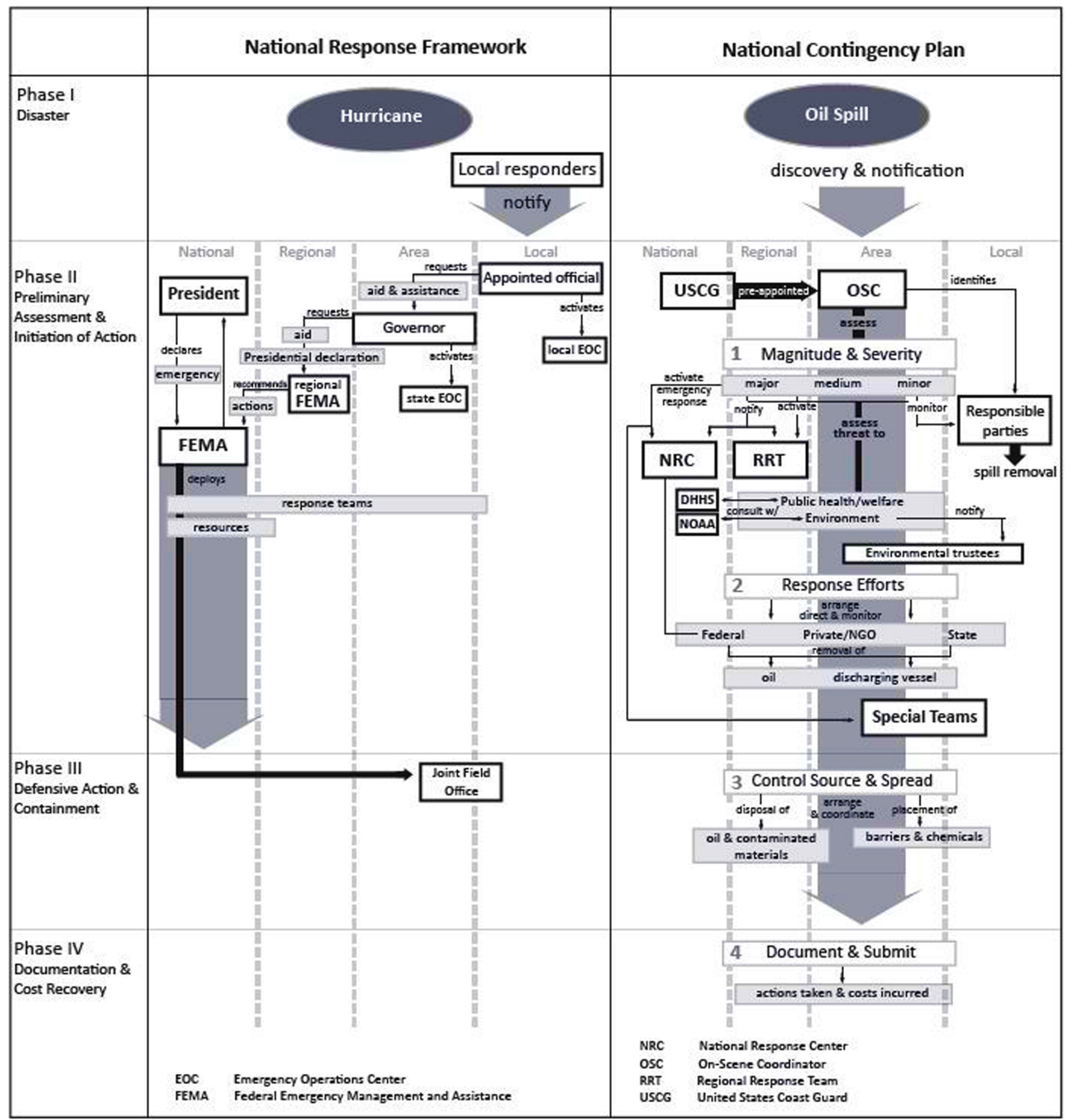

Environmental Protection Agency, for instance, co-signed on the decision concerning the use of dispersants, and the ad hoc team of federal agencies created by the National Incident Command made decisions about fishery closures without conflict with the structure of the National Contingency Plan (Osofsky 2011). A more conflicted relationship surfaced between governments at state and local levels as they tried to protect their communities using the measures that were more familiar to them.

At the state level, the state on-scene coordinator represents state and local responses to oil spills. The coordinator draws up spill contingency plans with the Coast Guard and a committee of 
federal, state, and local officials. Its staff decreased by half in the past 10 years, and its research and development program suffered a large budget cut in 2009 (Robertson and Rudolf 2010). Given these cuts as well as the magnitude of the Deepwater Horizon spill, the existing plan did not adequately serve its purpose and was considered ineffective in representing state and local interests. The Coast Guard, for instance, had to revamp the area contingency plan because it was not designed for such a large spill. It was also difficult to integrate the state oil spill response plan into the decision-making structure of the National Contingency Plan because of its small scale and the Coast Guard's unfamiliarity with subnational plans (Osofsky 2011). As a result, the Coast Guard established the Liaison Officer (LNO) Program consisting of over 70 mid-grade or senior Coast Guard officers to link local officials, the Coast Guard, and BP (United States Coast Guard 2011a,b).

The state also declared a state of emergency so that internal disaster funding and resources could be used for response activities. Such declarations, however, added another layer of command to the existing National Contingency Plan structure that already included the state on-scene coordinator. For example, Louisiana state representatives at the Unified Area Command had to consult the governor's office before approving daily response activities with other representatives at the Unified Command (National Commission on the BP Deepwater Horizon Oil Spill and Offshore Drilling 2010, Osofsky 2011).

Despite additional layers to the command structure, the state involvement that expanded beyond the National Contingency Plan had some positive effects. One was the supply of emergency managers to compensate for the shortage of personnel in the face of the largest spill in U.S. history. The state emergency department also expedited the spill response by shortening a decision process that usually takes at least 24 hours to complete. What it did was to help decentralize clean-up activities and respond efficiently to follow the fast-moving oil by implementing the federal operation in strategic locations. In these locations, the Coast Guard assessed the spill, instructed and approved a cleanup method, and supervised those contracted to do the cleaning.

As of July 2013, one point of contention between the state and the federal agencies was the timing of the cleanup operation shutdown. Because cleanup has gone on for more than three years, the federal agencies and BP have planned to exit. The state government, however, prefers that the Coast Guard, BP, and the NOAA continue their response operation, and did not approve a plan to transition from the emergency cleanup to long-term recovery (Schleifsten 2012). After the transition, the state will use its regular channel, that is, the Coast Guard's National Response Center, to report spills. The state complains that this regular reporting takes seven to 10 days to process. The state also notes that it is difficult to spot and report oiled beaches because people seldom walk on Louisiana beaches in the wetlands. Reporting oil spill damage is important to prove and assess the damage to the natural resource, and the slower reporting process can affect the extent of ongoing natural resource damage assessment.

At the local level, governments (parishes in Louisiana) felt powerless during the oil spill because they were not able to do much. The spill occurred on federal water and cleanup was considered specialized so that locals were not able to participate without proper training. Furthermore, the beaches that they considered their own were not accessible during cleanup. This was not the case during hurricanes when local officials knew what to do and how to deal with FEMA. With such knowledge, the officials could make requests that were acceptable. The parish president in Lafourche commented that "we are schooled in FEMA. We knew what we were doing." With the oil spill, it was frustrating because "we did not know what was acceptable," and "justifying our requests was onerous." Such unfamiliarity is one consequence of the changed authority and regulations as coastal Louisiana dealt with its largest oil spill.

Locals, moreover, felt that they were out of the loop and marginalized. They deplored the lack of direct communication during the oil spill, compared to the situation during hurricanes. For example, Louisiana Sea Grant field agents were able to contact the parish president and administrators directly to assist coastal communities with flood responses. During the oil spill, all the information had to go through the Unified Command. The Sea Grant agents had to contact their representative at the Unified Command to get information. This considerably delayed providing answers to people. Because local consultation was not set up initially, the Unified Command also did not immediately understand the value of a representative from state and local bodies such as the Sea Grant.

Eventually, the federal government heeded local concerns. The Department of Homeland Security and the National Incident Commander instructed the Unified Command to "do whatever it takes to make the Parishes happy" (United States Coast Guard $2011 b$ ). This directive pushed the Unified Command to reexamine its operational objectives and appease local officials. Though the Unified Command started to consult locals, it was not required to implement their requests according to the Coast Guard staff. This was difficult for locals to accept because they expected to have the same control that they had exercised during the hurricane crises.

Because of new regulations and authorities, local governments formed new ties. Parishes sent representatives to the Unified Command. What most parishes also realized was that it is wise to work with the Coast Guard from the beginning to understand how the response system works. Local governments also got in touch with the private sector such as $\mathrm{BP}$ and the rig owners. Terreborne emergency management, for example, contacted BP in the early weeks of the spill and asked what they could do to help in an effort to build a good relationship. This network was facilitated by the fact that the lead emergency manager knew the BP personnel prior to the spill. Likewise, the parish president in Lafourche said that it is good to develop links with the owners of the rig and the former Minerals Management Service so that if another accident happens, they would "know who we are". Because they did not establish ties with them previously, the locals were, in a sense, "dehumanized."

\section{Changed focus to environment}

The unfamiliarity with a new set of laws and regulations and different personnel/staff in charge at the federal level have caused stress and frustration, especially in the initial phase of the response. The difference in laws and regulations has also generated a perception that people are not as important as the environment. The emphasis on the oil spill's damage to the environment has 
caused resentment because people perceive the focus to be on saving the environment instead of caring for the welfare of the affected coastal residents. The establishment of the Natural Resource Damage Assessment program especially caused much concern because residents felt the Oil Pollution Act favored ecosystem recovery in lieu of human recovery.

This concern was somewhat alleviated by the funneling of emergency funds to the affected residents, the Vessel of Opportunity program, and compensation for economic loss. Nonetheless, the major emphasis is considered to be on the environment. The Restore Act of July 6, 2012, for instance, is designed to restore the coastal environment. The money will be divided between the five Gulf states, the Gulf Coastal Ecosystem Restoration Council consisting of representatives from the U.S. Departments of Interior, Army, Commerce, Agriculture, Environmental Protection Agency, Coast Guard, and five Gulf states, and 5 percent towards research (Harrison 2013). Though the restoration fund includes community resilience and economic development such as job creation, tourism, and the promotion of seafood consumption, it is, thus far, predominantly focused on ecosystem restoration with a lack of attention to socioeconomic conditions (Harrison 2013).

Hurricanes, on the other hand, place people at the center. Everyone and their homes and possessions are affected by hurricanes. Destruction is parish-wide. Evacuation and human loss can shake the core of the community as people may lose everything they own as a former Sea Grant staff member notes. It is different with an oil spill. Everything runs as it is supposed to, and not everyone is affected. Other than the blowout, there is no human loss. He comments that an oil spill is a nuisance and a hurricane is a heartache.

In this light, people have complained that the oil spill response was disconnected from affected communities (Monitor's Editorial Board 2010). The Coast Guard was perceived to perform its duties mechanically without much understanding of community impact. FEMA was considered more compassionate and humane as it better understood the human impact (Sylves and Cumming 2004). A former FEMA employee and disaster consultant deplored the Coast Guard's lack of focus on locals such as fishermen, tour operators, and the local government that FEMA worked well with (Borenstein 2010).

\section{Uncertainty}

Uncertainty is at the heart of oil spill concerns. This uncertainty is primarily attributed to the magnitude of the spill because the long-term effects of the U.S.'s largest spill are difficult to assess. Fishermen are especially worried about the lasting effects of dispersants on fish and fish habitats. Unlike the hurricane, a state emergency manager remarks that the oil spill is said to linger like a "slow torture." Federal agencies say they are still responding and cleaning up after three years. Seafood safety is also a protracted concern. Receiving compensation takes time. For local governments, spill-related issues erupt occasionally, even after three years. The longevity of spill cleanup and compensation has, thus, contributed to the heightened sense of uncertainty.

High uncertainty after the oil spill, however, has more to do with the novelty of the disaster and the accompanying regulatory change than the specific characteristics of the spill such as its size and the longevity of its effects. Unfamiliarity with the Oil Pollution Act resulted in uncertainty about how governments and communities at the local and state level could or should respond to the spill. They, therefore, had to depend on others to respond and learn to adapt. On the other hand, a hurricane is considered a known hazard that people are used to. People know how to handle it. Emergency managers utilize established contracts set up with debris removers and other service providers in preparation for hurricanes. Parishes set aside money to cope with the aftermath of hurricanes. The parish president in Terreborne says, "We know what to do, and we know it will get better."

\section{CONCLUSION}

The discourse concerning the transition from hurricanes to the oil spill in terms of disaster response often centers on the difference between a man-made disaster with a responsible party (in this case, BP) and a natural disaster without a specific entity to blame. It also entails the presence or absence of litigation. They all may be part of the way disaster response is different with respect to the Deepwater Horizon oil spill. What is central, however, is that there are structural differences in regulations that dictate the way governments and communities respond and adapt to the oil spill. The new set of regulations during the Deepwater Horizon oil spill, unlike the regulations governing the response to hurricanes, formed barriers to adaptation to this new disaster.

Governments at the federal, state, and local levels had difficulties adjusting to new rules and changed authorities, and they, in turn, generated uncertainty and frustration among the people of coastal Louisiana. State officials and locals were more involved than specified in the Unified Command procedure under the Oil Pollution Act. The focus on the environment compared to the human-centered hurricane response also separated people and the environment in the minds of people. The interactive nature of people and the environment essential for recovery from the oil spill was a missing consideration. Though people may believe that uncertainty derives from a lack of knowledge about long-term effects of the spill, both the unfamiliarity of the spill and the unfamiliarity with the different regulations designed to respond to the spill underlie people's sense of uncertainty.

What proved vital in adapting to the spill disaster was a set of networks available to reach out not only to existing partners but also to new ones. As new authorities and organizations flow into communities, it is important that governments and communities interact with them, form new partnerships, and establish mutual understanding. Newly formed networks are not necessarily systematic, and they tend to be dependent on the skills of an individual. The next step is to turn them into a more systematic and routine set of arrangements. The capacity of the Gulf region to renew efforts at coastal restoration and include more versatility in disaster preparation after this spill can enhance the overall resilience to disasters. This is reflective of disaster resilience based on all-inclusive collaborations, combined efforts, and shared responsibilities (National Academies 2012).

\section{Responses to this article can be read online at: http://www.ecologyandsociety.org/issues/responses. $\mathrm{php} / 6382$}




\section{Acknowledgments:}

This research is supported by the NSF CAREER Award\#1151288.

\section{LITERATURE CITED}

Birkland, T. A., and S. E. DeYoung. 2011. Emergency response, doctrinal confusion, and federalism in the Deepwater Horizon oil spill. Journal of Federalism 41(3):471-493.

Borenstein, S. 2010. Wishing upon a czar: experts want oil-spill chief. Houma Today May 27, 2010. [online] URL: http://www. houmatoday.com/article/20100527/ARTICLES/100529352

Bulkeley, H. and K. Kern. 2006. Local government and the governing of climate change in Germany and the UK. Urban Studies 43(12):2237-2259. http://dx.doi.org/10.1080/00420980600936491

Burby, R. J. 2006. Hurricane Katrina and the paradoxes of government disaster policy: bringing about wise governmental decisions for hazardous areas. ANNALS of the American Academy of Political and Social Science 604:171-191. http://dx. doi.org/10.1177/0002716205284676

Depoorter, B. 2006. Horizontal political externalities: the supply and demand of disaster management. Duke Law Journal 56:101-127.

Elo, S., and H. Kyngäs. 2008. The qualitative content analysis process. Journal of Advanced Nursing 62(1):107-115. http://dx.doi. org/10.1111/j.1365-2648.2007.04569.X

Foley, V. J. 2011. Post-Deepwater Horizon: the changing landscape of liability for oil pollution in the United States. Albany Law Review 74:515-530.

Geiser, U., and S. Rist, editors. 2009. Decentralization meets local complexity: conceptual entry points, field-level findings and insights gained. Pages 15-55 in Decentralisation meets local complexity: local struggles, state decentralisation and access to natural resources in South Asia and Latin America perspectives. Geographica Bernesia/ Swiss National Centre of Competence in Research (NCCR) North-South, Bern, Switzerland.

Griggs, J. W. 2011. BP Gulf of Mexico oil spill. Energy Law Journal 32:57-79.

Gunderson, L. 2010. Ecological and human community resilience in response to natural disasters. Ecology and Society 15(2):18. [online] URL: http://www.ecologyandsociety.org/vol15/iss2/ $\underline{\operatorname{art18/}}$

Harrison, R. W. 2013. The Restore Act of 2012: implications for the Gulf Coast. Journal of Agricultural and Applied Economics 45 (3):331-337.

Longstaff, P. H., and S. Yang. 2008. Communication management and trust: their role in building resilience to "surprises" such as natural disasters, pandemic flu, and terrorism. Ecology and Society 13(1):3. [online] URL: http://www.ecologyandsociety. org/vol13/iss 1/art3/

Monitor's Editorial Board. 2010. Lesson from the Gulf oil spill: listen to the locals. Christian Science Monitor July 1, 2010. [online] URL: http://www.csmonitor.com/Commentary/the-monitorsview/2010/0701/Lesson-from-the-Gulf-oil-spill-Listen-to-the-locals
National Academies. 2012. Disaster resilience: a national imperative. National Academies, Washington, D. C., USA.

National Commission on the BP Deepwater Horizon Oil Spill and Offshore Drilling. 2010. Decision-making within the unified command. Staff Working Paper No. 2. Oil Spill Commission Action. [online] URL: http://oscaction.org/resource-center/staffpapers/

Osofsky, H. M. 2011. Multidimensional governance and the BP Deepwater Horizon oil spill. Florida Law Review 63(5):1077.

Reddy, S. D. 2000. Factors influencing the incorporation of hazard mitigation during recovery from disaster. Natural Hazards 22(2):185-201.

Ribot, J., A. Agrawal, and A. Larson. 2006. Recentralizing while decentralizing: how national governments reappropriate forest resources. World Development 34(11):1864-1886. http://dx.doi. org/10.1016/j.worlddev.2005.11.020

Robertson, C., and J. C. Rudolf. 2010. Louisiana wants U.S. Help, and its own way. The New York Times June 25, 2010. [online] URL: http://www.nytimes.com/2010/06/26/us/politics/26jindal. $\underline{h t m l \text { pagewanted }=\text { all \& } \mathrm{r}=0}$

Schleifsten, M. 2012. Spilled BP oil lingers on Louisiana Coast. The Times Picayune April 21, 2012. [online] URL: http://www. nola.com/news/gulf-oil-spill/index.ssf/2012/04/spilled_bp_oil_lingers on loui.html

Sylves, R., and W. Cumming. 2004. FEMA's path to homeland security: 1979-2003. Journal of Homeland Security and Emergency Management 1(2):1-21.

United States Coast Guard. 2011a. On scene coordinator report: Deepwater Horizon oil spill. United States Department of Homeland Security, Washington, D. C., USA. [online] URL: http://www.uscg.mil/foia/docs/dwh/fosc dwh report.pdf

United States Coast Guard. 2011b. BP Deepwater Horizon oil spill: incident specific preparedness review. United States Department of Homeland Security, Washington, D. C., USA. [online] URL: http://www.uscg.mil/foia/docs/dwh/bpdwh.pdf 